University of Nebraska - Lincoln

DigitalCommons@University of Nebraska - Lincoln

Entomology Papers from Other Sources

Entomology Collections, Miscellaneous

1988

Diets of Darkling Beetles (Coleoptera: Tenebrionidae) Within a Shrub-Steppe Ecosystem

L. E. Rogers

Environmental Sciences Department, Pacific Northwest Laboratory, Richland, Washington

N. E. Woodley

Environmental Sciences Department, Pacific Northwest Laboratory, Richland, Washington, norman.woodley@ars.usda.gov

J. K. Sheldon

Environmental Sciences Department, Pacific Northwest Laboratory, Richland, Washington

P. A. Beedlow

Environmental Sciences Department, Pacific Northwest Laboratory, Richland, Washington

Follow this and additional works at: https://digitalcommons.unl.edu/entomologyother

Part of the Entomology Commons

Rogers, L. E.; Woodley, N. E.; Sheldon, J. K.; and Beedlow, P. A., "Diets of Darkling Beetles (Coleoptera: Tenebrionidae) Within a Shrub-Steppe Ecosystem" (1988). Entomology Papers from Other Sources. 57. https://digitalcommons.unl.edu/entomologyother/57

This Article is brought to you for free and open access by the Entomology Collections, Miscellaneous at DigitalCommons@University of Nebraska - Lincoln. It has been accepted for inclusion in Entomology Papers from Other Sources by an authorized administrator of DigitalCommons@University of Nebraska - Lincoln. 


\title{
Diets of Darkling Beetles (Coleoptera: Tenebrionidae) Within a Shrub-Steppe Ecosystem
}

\author{
L. E. ROGERS, N. E. WOODLEY, ${ }^{1}$ J. K. SHELDON, ${ }^{2}$ AND P. A. BEEDLOW \\ Environmental Sciences Department, Pacific Northwest Laboratory, \\ Richland, Washington 99352
}

\begin{abstract}
Ann. Entomol. Soc. Am. 81(5): 782-791 (1988)
ABSTRACT The diets of 13 species of darkling beetles inhabiting shrub-steppe communities of southcentral Washington were analyzed. Forty-seven vascular plant species, including 7 grasses, 34 forbs, and 6 shrubs, were fed upon. Cluster analysis was used to determine the extent of overlap in food habits among beetle species. The beetle species were separated into five food preference groups. Partitioning of food resources may act to refine niche space of these beetles.
\end{abstract}

KEY WORDS Insecta, darkling beetles, dietary niches, Tenebrionidae

DARKLING BEETLES are a conspicuous part of the invertebrate fauna in the semiarid regions of the western United States. Their abundance in shrubsteppe and desert regions (Rickard \& Haverfield 1965, Hinds \& Rickard 1973, Rogers \& Rickard 1975, Sheldon \& Rogers 1984) suggests that they play an important role in the functioning of these ecosystems.

Understanding the diets of major consumers is essential in understanding ecosystem functioning, because consumption serves as a control point for materials entering transport pathways. Our objective was to describe the dietary relationships of darkling beetles occupying shrub-steppe communities of the Hanford Site in southcentral Washington.

\section{Materials and Methods}

This research was conducted on lands owned by the U.S. Department of Energy and known ad-

${ }^{1}$ Current Address: Systematic Entomology Laboratory, USDA, U.S. National Museum, Washington, D.C. 20560.

${ }^{2}$ Current Address: Biology Department, Eastern College, St. Davids, Pa. 19087. ministratively as the Hanford National Environmental Research Park (NERP). The Hanford NERP extends over 148,000 ha ( 570 square miles) of relatively pristine shrub-steppe vegetation in southcentral Washington. Nine study sites were selected within major biotic communities (Table 1); they have been described by Sheldon \& Rogers (1984).

Twenty-five pitfall traps were placed in a straight line at 5-m intervals at each study site. Each trap was a metal can ( 9 by $9 \mathrm{~cm}$ ) buried flush with the soil surface. A $5 \%$ formalin solution maintained to within $2.5 \mathrm{~cm}$ of the rim of the traps quickly killed the beetles and stopped digestion. The traps were emptied weekly from March through October during a 2 -yr period. The digestive tract was removed from each beetle, cleared with Hertwig's solution, and prepared for microscopic analysis as described by Sparks \& Malechek (1968), Hansen \& Flinders (1969), and Rogers \& Uresk (1974).

We prepared reference slides of all plant species known to occur within the study sites. Plant samples (including leaves, stems, and flowers) were dried, partially ground ( $1 \mathrm{~mm}$ screen size), and mounted separately. Prepared slides of beetle digestive tracts were sent to the Composition Analysis Laboratories, Colorado State University, Ft.

Table 1. Study sites

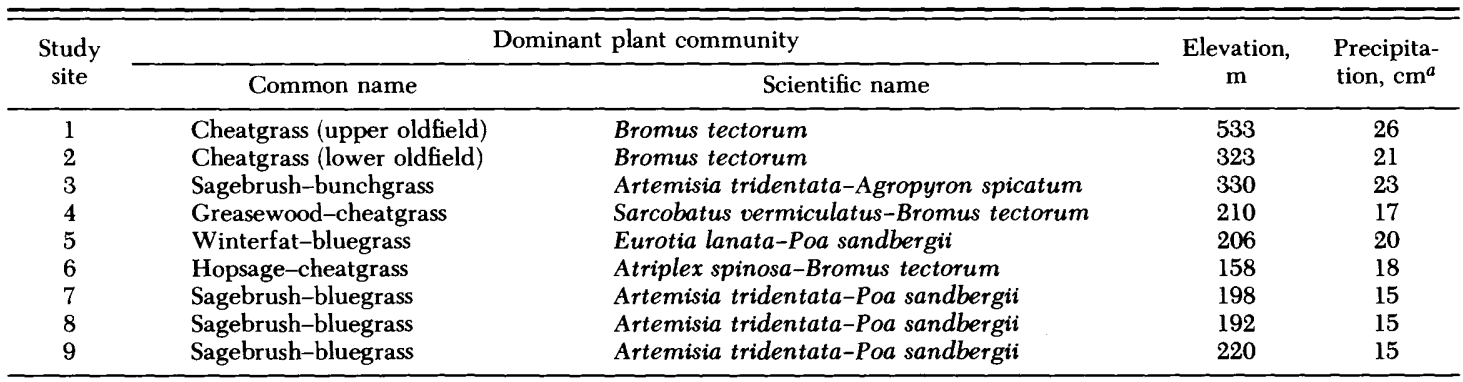

${ }^{a}$ From Stone et al. 1972

0013-8746/88/0782-0791\$02.00/0 (C) 1988 Entomological Society of America

This article is a U.S. government work, and is not subject to copyright in the United States. 
Site 7

Sagebrush/

Bluegrass

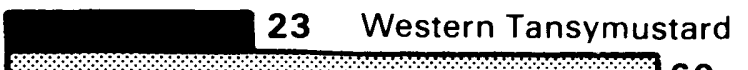

\section{Site 2
Cheatgrass}

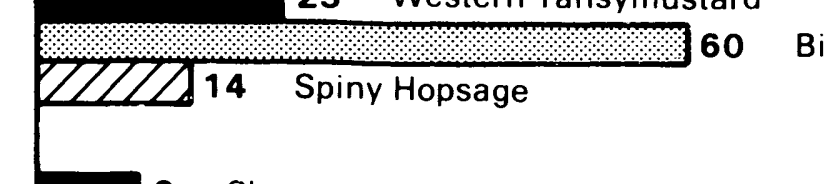

Big Sagebrush

\begin{tabular}{ll}
9 & Cheatgrass \\
\hline 74 & Big Sagebrush \\
8 & Pollen
\end{tabular} 6

Jim Hill

Mustard

\section{Site 4 \\ Greasewood/ \\ Cheatgrass}

Site 6

Hopsage/

Cheatgrass

Site 3

Sagebrush/

Bunchgrass
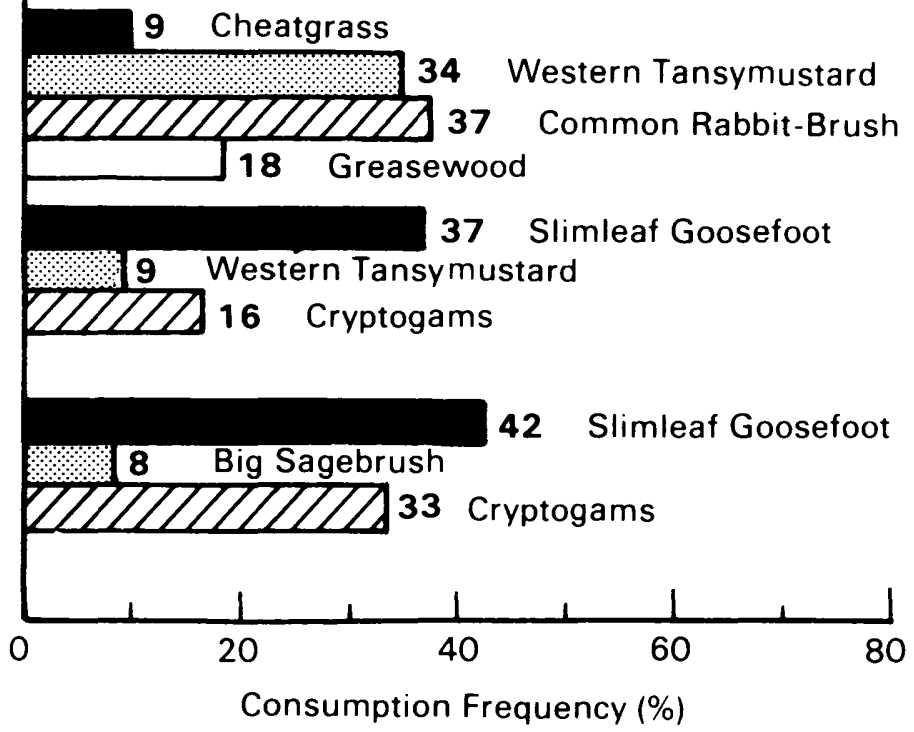

Fig. 1. Consumption frequency (\%) of major plant species by C. setosa.

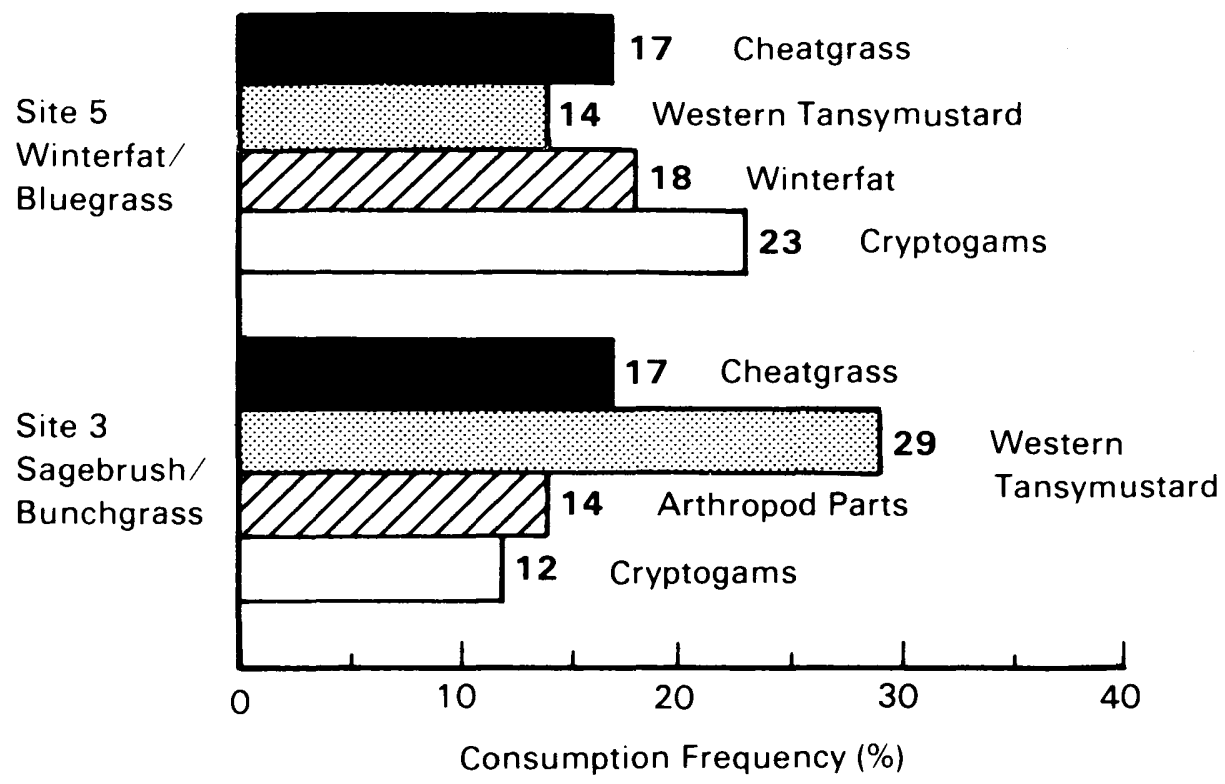

Fig. 2. Consumption frequency (\%) of major plant species by E. granulata. 


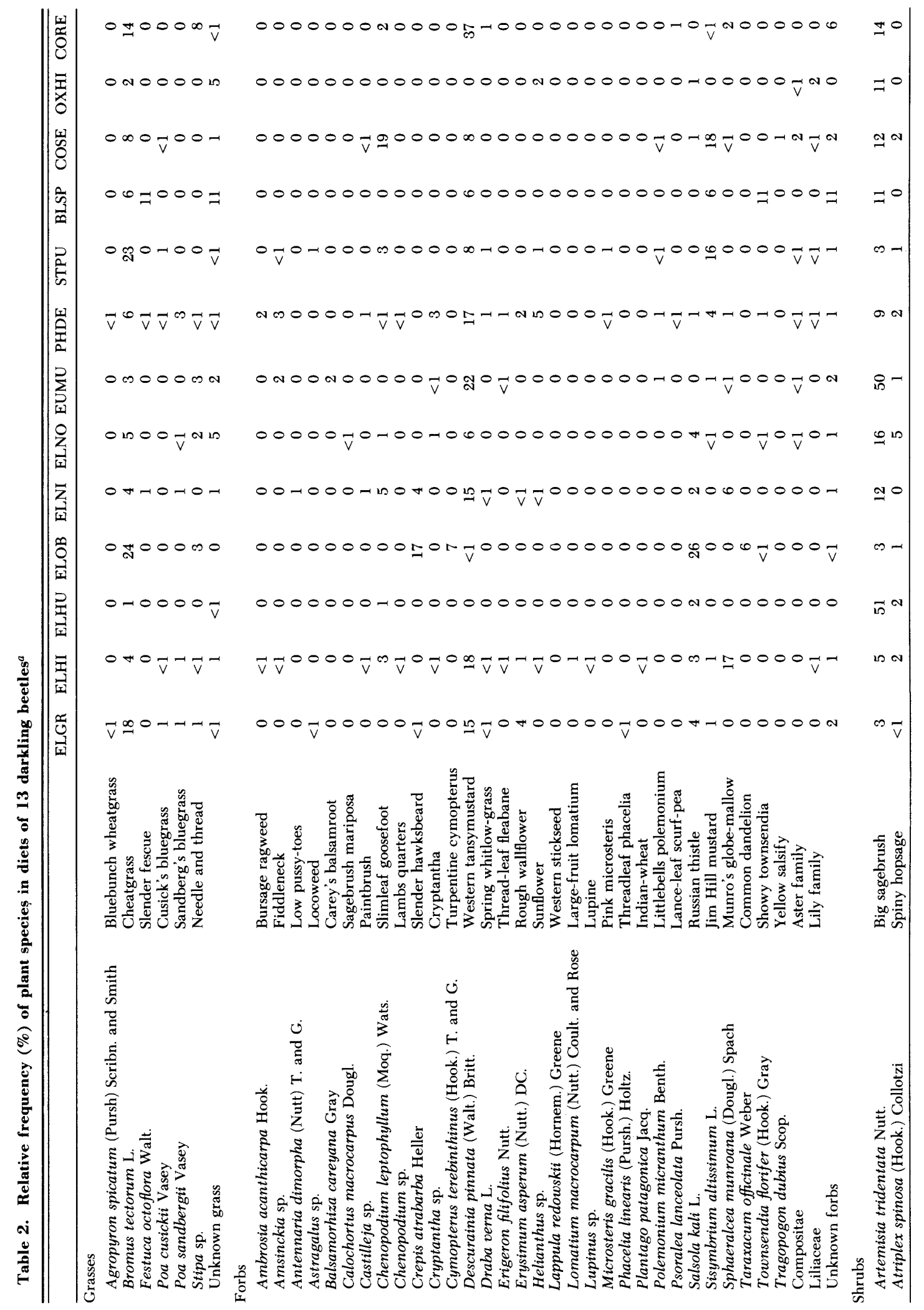




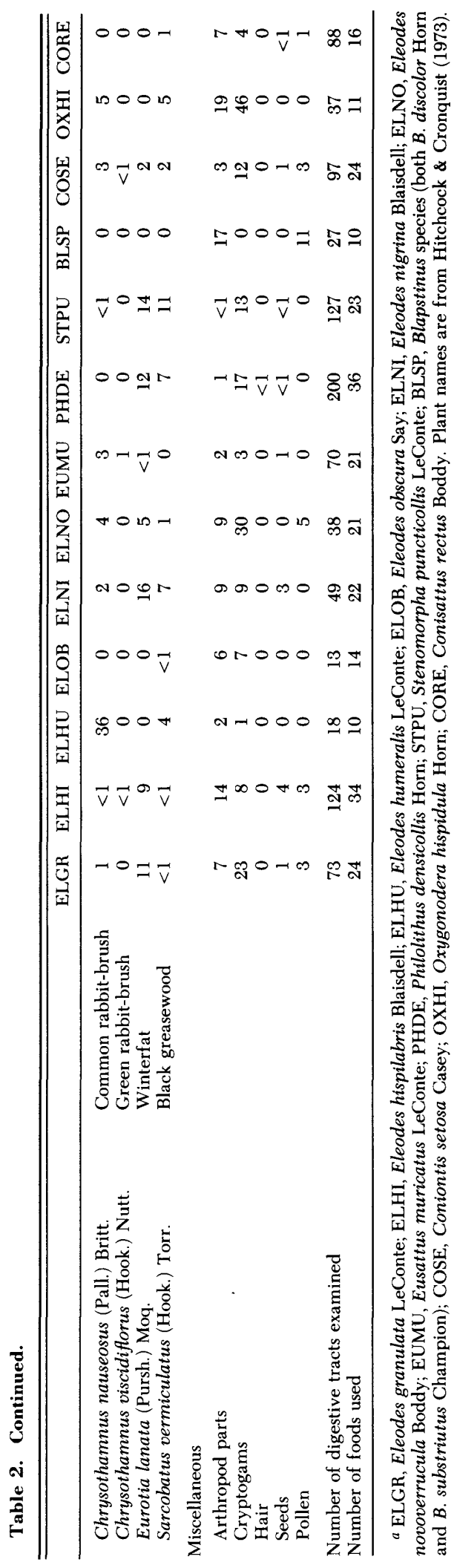

Collins, together with plant reference slides for analysis. Twenty microscope fields were read from each slide, and the frequency of occurrence of each plant species was calculated (Table 2).

Niche overlap was calculated for each species based on food items found in the gut analysis (see Pianka 1975, Wiens \& Rotenberry 1979) from the formula:

$$
0=\frac{\sum_{i}^{n} p_{i} q_{i}}{\sqrt{\sum_{i}^{n} p_{i}{ }^{2} \sum_{i}^{n} q_{i}{ }^{2}}}
$$

where $p_{i}$ is the relative frequency of a diet item in the diet of a given taxon, and $q_{i}$ is the relative frequency of a diet item in another taxon. Cluster analysis was used to compare dietary niche overlap among beetle species (Hartigan 1975).

\section{Results}

Thirteen species of darkling beetles in eight genera were collected, and their food was analyzed. Digestive tracts of 960 individuals were examined, and a total of 52 different food items were recorded: 7 grass, 34 forb, 6 shrub, and 5 miscellaneous food types (Table 2). Four beetle species were abundant on five sites, three on three sites, one on two sites, and five on only one site. Comparisons of foods habits of species occupying more than one study location are shown in Fig. 1-8. Only those plant species consumed at a frequency greater than $7 \%$ are included.

Blapstinus substriatus Champion and B. discolor Horn. Ten food plants were identified in Blapstinus diets (Table 2). Fragments of arthropod parts comprised $17 \%$ of the diet. These are small beetles, and some arthropod fragments may be artifacts associated with our dissection and mounting. Plant pollen, big sagebrush, slender fescue, needleand-thread grass, Townsendia, and unknown forbs each comprised $11 \%$ of the diet. Blapstinus was abundant only in the old field communities, and diets were analyzed only at the lower old-field community (Site 2).

Coniontis setosa Casey. Twenty-four different food items were ingested by this beetle (Table 2). The most frequent were slimleaf goosefoot (19\%), Jim Hill mustard (18\%), big sagebrush (12\%), and cryptogams $(12 \%)$. Food selection changed at different sites (Fig. 1). Big sagebrush was frequently consumed at the sagebrush-bluegrass community (Site 7) but accounted for less than $10 \%$ of the diet in other areas. Major food plants at other sites were Jim Hill mustard in the lower old field (Site 2); western tansymustard and rabbitbrush in the greasewood community (Site 4); and slimleaf goosefoot and cryptogams in the hopsage-cheatgrass community (Site 6).

Conisattus rectus Boddy. C. rectus $(=C$. nelsoni [Doyen 1984]) was abundant only in the sagebrush- 


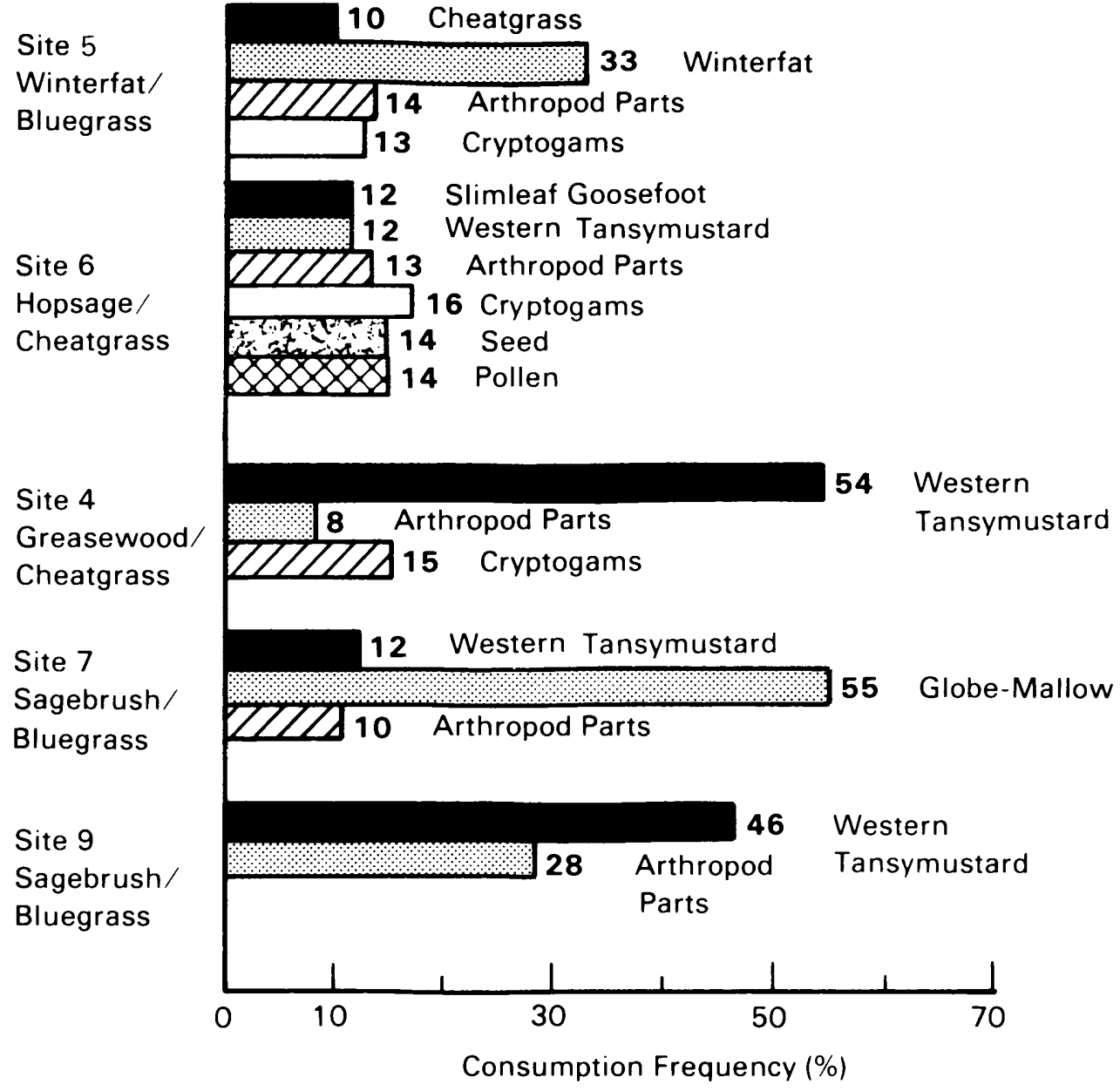

Fig. 3. Consumption frequency (\%) of major plant species by E. hispilabris.

bluegrass community (Site 7) during this study, and this analysis reflects only those food items available in that community (Table 2). Although diet for this species included 16 food items, only three had a high ingestion frequency: western tansymustard $(37 \%)$, cheatgrass (14\%), and big sagebrush (14\%).

Eleodes granulata LeConte. Twenty-four food items were consumed by this species (Table 2). Major food items were cryptogams (23\%), cheatgrass $(18 \%)$, western tansymustard $(15 \%)$, and winterfat $(11 \%)$. All others comprised $7 \%$ or less of the diet. Consumption frequency for the two sites where this species was abundant is shown in Figure 2.

Eleodes hispilabris Blaisdell. A total of 34 food items was consumed by this species (Table 2). Forbs were the most important category of food plants; only western tansymustard (18\%) and globe-mallow $(17 \%)$ were abundant in their diet. The many different food items consumed (mostly at low frequencies) and the shift in food items taken from different study sites (Fig. 3) indicate that $\boldsymbol{E}$. hispilabris is an omnivorous feeder.

Eleodes humeralis LeConte. There were 10 food items in the diet of $E$. humeralis, all but two of them incidental (Table 2). In the greasewood community (Site 4), big sagebrush $(51 \%)$ and rabbitbrush (36\%) were the most important plant species in the diet. This supports field observations that $E$. humeralis occurs in abundance only in shrub-dominated areas (Sheldon \& Rogers 1984). E. humeralis is obviously a stenophage.

Eleodes nigrina Blaisdell. Twenty-two food items were consumed by this species (Table 2). Most frequently consumed were winterfat $(16 \%)$, western tansymustard (15\%), and big sagebrush (12\%). Grasses were an insignificant part of the diet.

Populations inhabiting specific communities seemed to adjust their feeding to available plant species (Fig. 4). In the winterfat community (Site 5 ), this beetle concentrated on winterfat and arthropod parts but took little sagebrush or western tansymustard. In the greasewood community (Site 4), greasewood was the most frequently consumed shrub, although sagebrush was also eaten. Both western tansymustard and cryptogams were also frequently ingested. Beetles in the sagebrush-blue- 


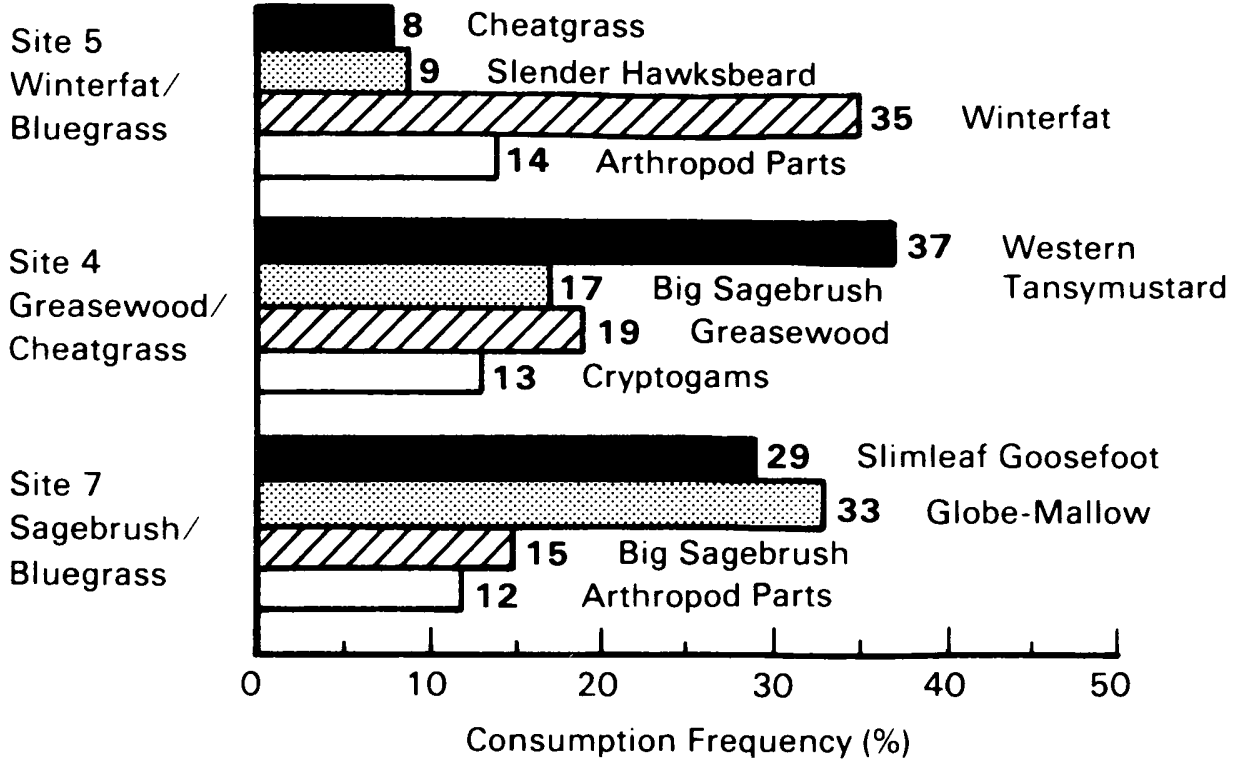

Fig. 4. Consumption frequency (\%) of major plant species by E. nigrina.

grass community (Site 7) selected sagebrush, globemallow, goosefoot, and arthropod parts.

Eleodes novoverrucula Boddy. This darkling beetle consumed 21 different food items (Table 2), preferring cryptogams (30\%) and big sagebrush (16\%). None of the other ingested food plants comprised more than $9 \%$ of the total diet.

There was a high ingestion frequency of sagebrush in the greasewood (Site 4), and winterfat (Site 5) communities, but a low one in the hopsage (Site 6) community, where cryptogams, hopsage, and Russian thistle were the major food items (Fig. 5).
Eleodes obscura Say. Fourteen food items were found in the diet of this species (Table 2). Russian thistle (26\%), cheatgrass (24\%), and slender hawksbeard (17\%) were the major plants in the diet. This beetle is not abundant, and only 13 individuals are included in this diet analysis; therefore, dietary preferences observed here may not be representative of the population as a whole.

Eusattus muricatus LeConte. Twenty-one food items occurred in the diet of $E$. muricatus (Table 2), which appears to be restricted to sandy habitats. Samples were collected only from Site 8 . Western

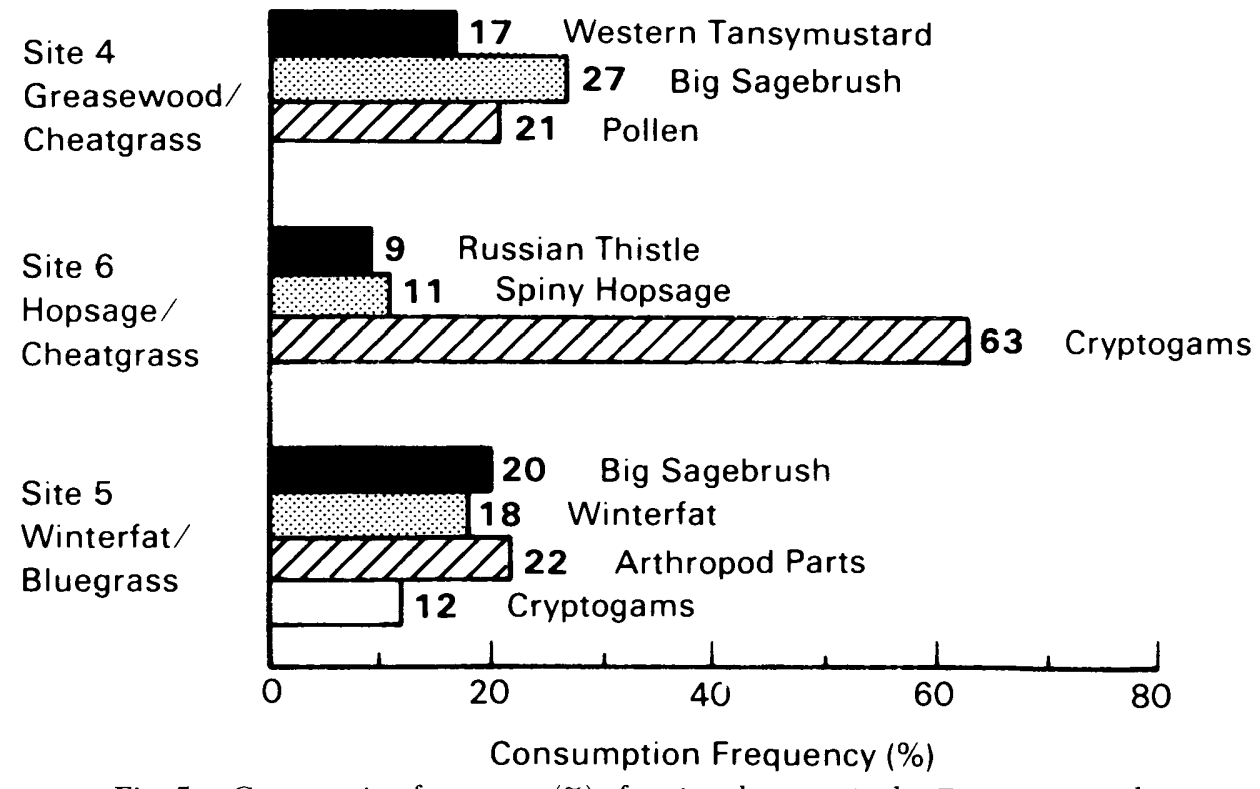

Fig. 5. Consumption frequency (\%) of major plant species by $E$. novoverrucula. 


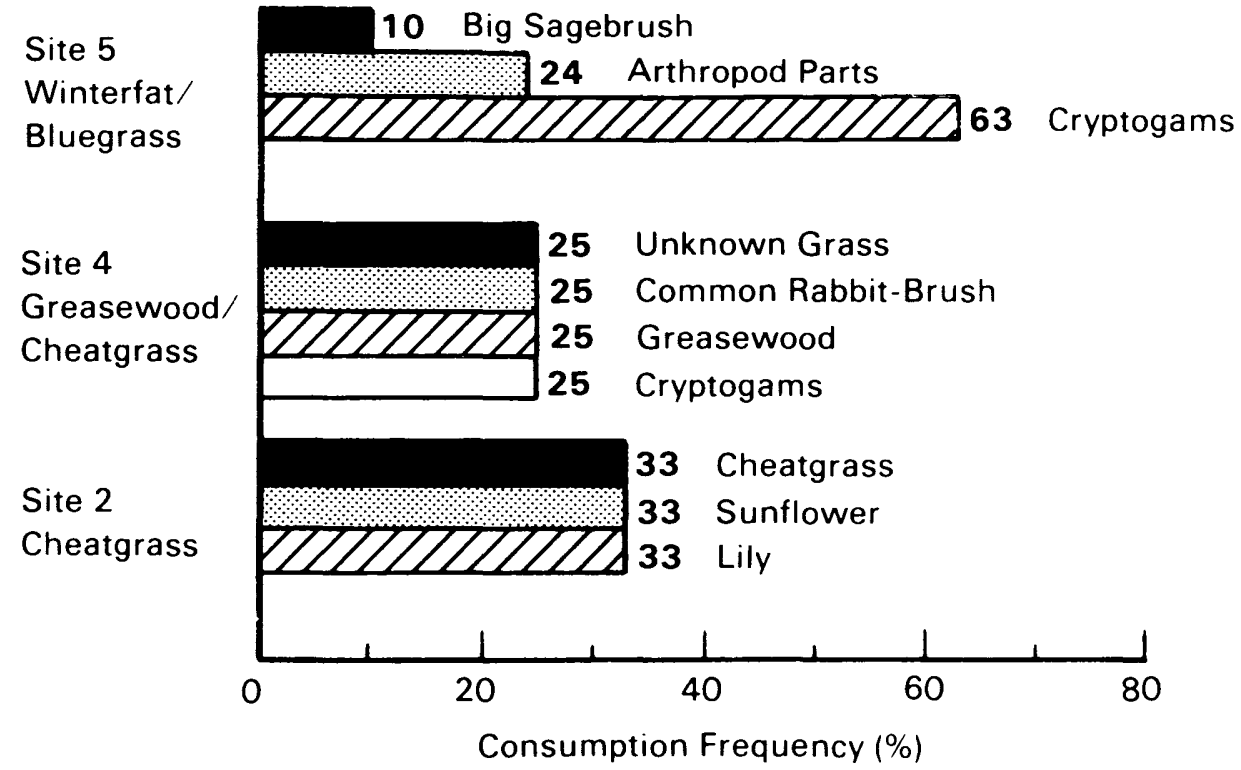

Fig. 6. Consumption frequency (\%) of major plant species by O. hispidula.

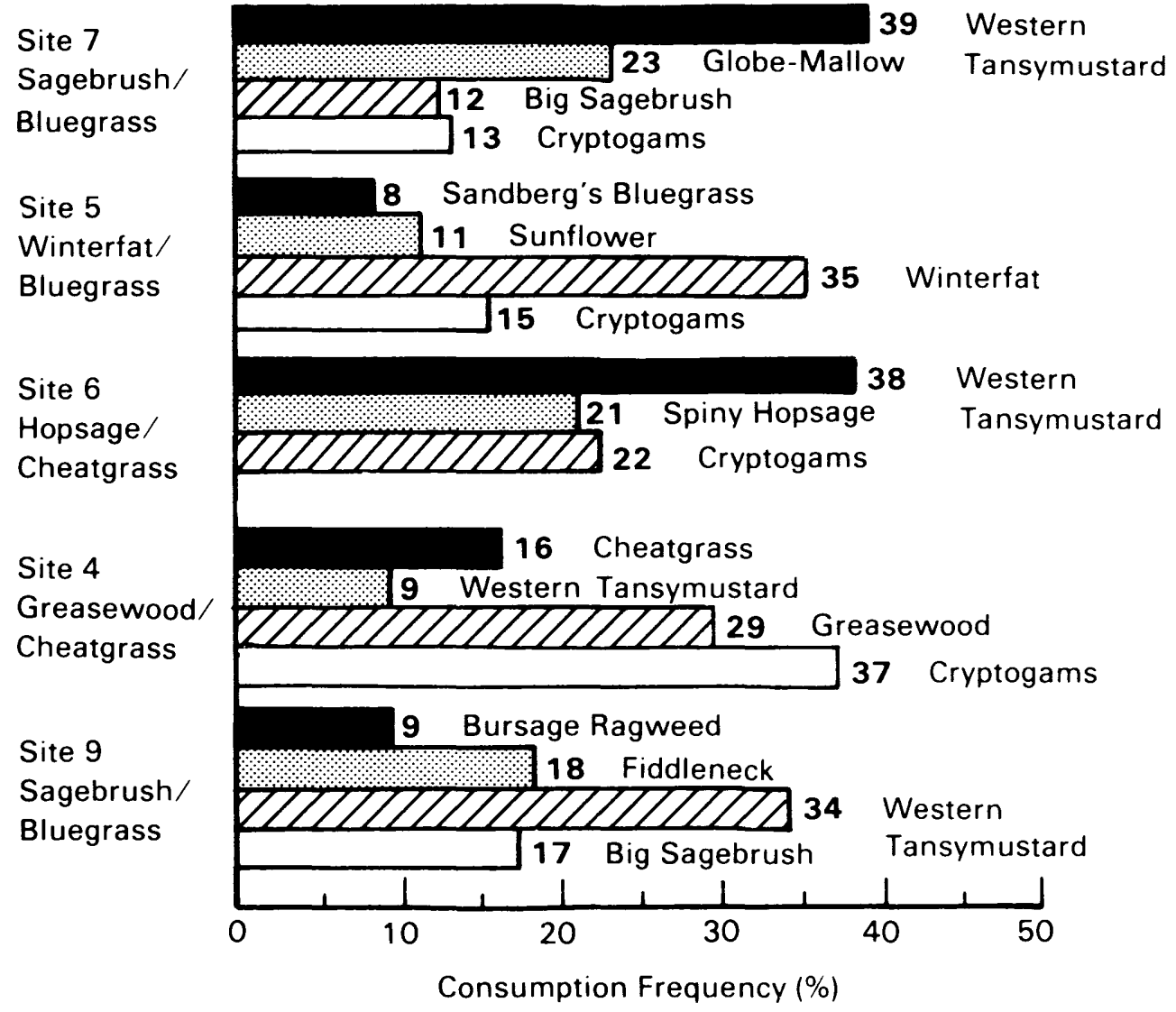

Fig. 7. Consumption frequency (\%) of major plant species by $P$. densicollis. 


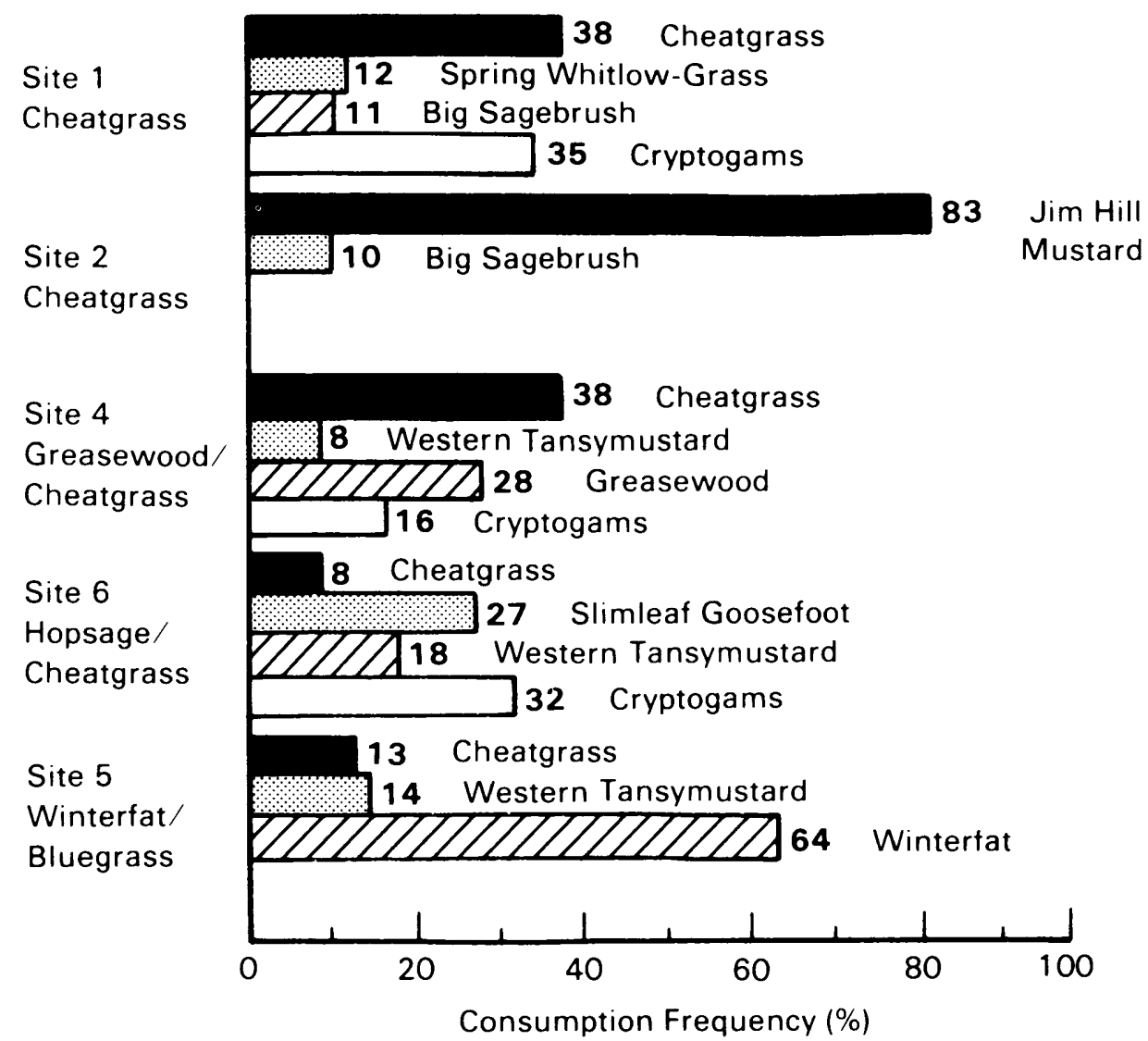

Fig. 8. Consumption frequency (\%) of major plant species by S. puncticollis.

tansymustard (22\%) and big sagebrush (50\%) were the only species consumed in large proportions. All other food items occurred in the diets with less than $3 \%$ frequency.

Oxygonodera hispidula Horn. This beetle consumed 11 different food items (Table 2). Only three-cryptogams (46\%), arthropod parts (19\%), and big sagebrush (11\%)-occurred with a high frequency across the sites where it was abundant (Table 2, Fig. 6).

Philolithus densicollis Horn. A total of 36 different food items was consumed by this species, the most recorded for any species in this study. Western tansymustard (17\%), cryptogams (17\%), winterfat (12\%), big sagebrush (9\%), and greasewood $(7 \%)$ were the most frequently consumed food items across sites (Table 2). This beetle is clearly an omnivorous feeder, but it tended to select western tansymustard, sagebrush, and cryptogams consistently. Cryptogams are an important diet component at nearly all study sites (Fig. 7).

Stenomorpha puncticollis LeConte. Twentythree food items were selected by this species (Table 2). Food items of importance include cheatgrass $(23 \%)$, Jim Hill mustard (16\%), winterfat (14\%), cryptogams $(13 \%)$, and greasewood $(11 \%)$. Cheatgrass was consumed at most study sites where this beetle was collected (Figure 8). The lack of cheatgrass consumption in the lower old field (Site 2) is associated with a high frequency of ingestion for Jim Hill mustard, the latter probably being preferred.

\section{Discussion}

Measurement of dietary niche overlap permits grouping of beetle cohorts with similar feeding patterns. Blapstinus spp. are not included in this analysis because specific determinations were not made between $B$. substriatis and $B$. discolor.

A dendrogram was constructed from dietary niche overlap data to show the relation between food habits (Fig. 9). The unweighted paired-group method of clustering resulted in the highest cophenetic correlation, a measure of agreement between the dendrogram and the initial measures of interobject distance; i.e., niche overlap (Hartigan 1975).

The diet of Eleodes obscura was distinct from those of the other beetles in containing only annual plant (weedy) species. All the other beetles contained perennial plants to varying degrees. E. humeralis and Eusattus muricatus formed a group 


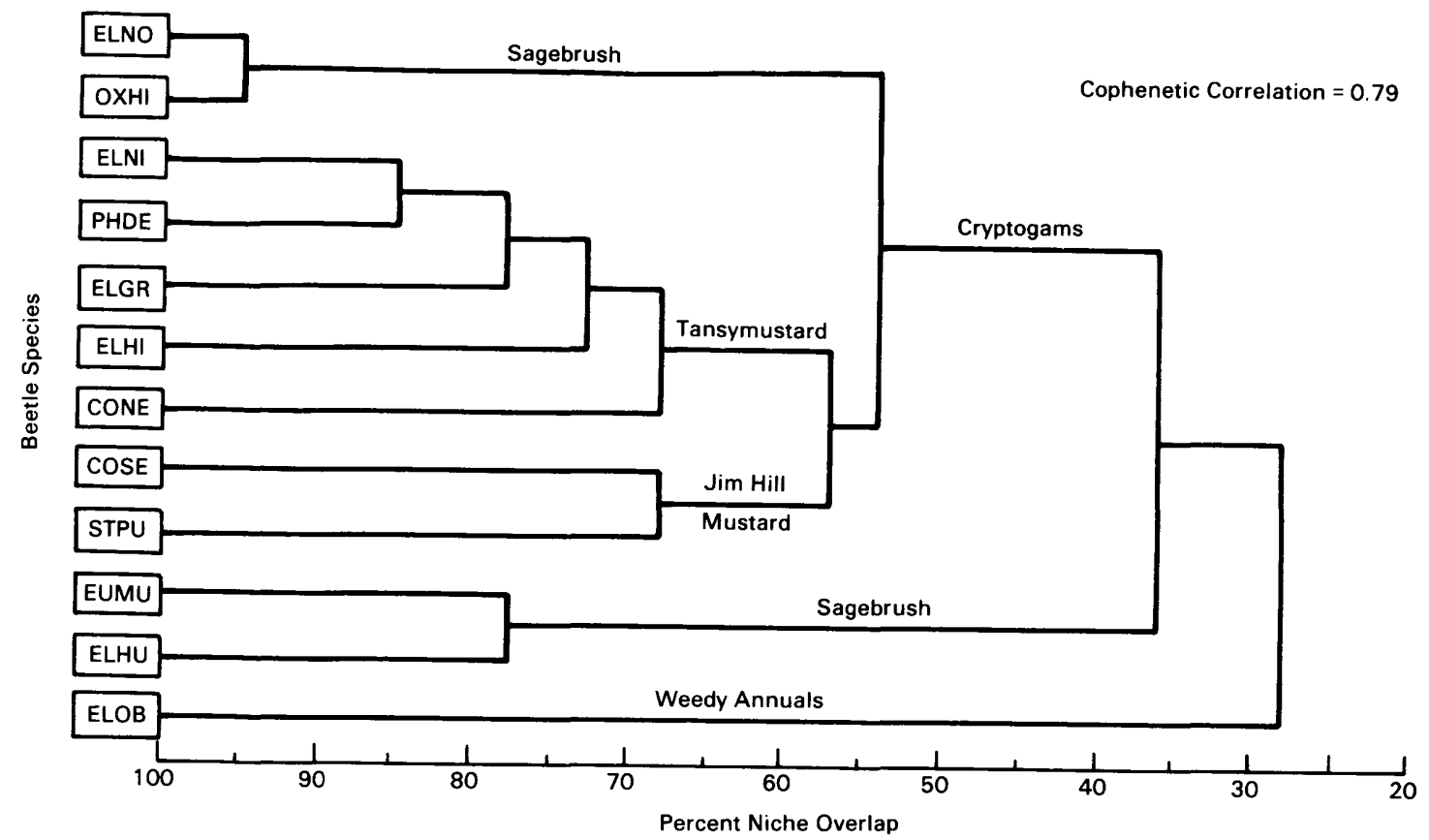

Fig. 9. Dendrogram constructed from dietary niche overlap data to show food habit relationships amidst beetle species. See footnote Table 2, for abbreviations of beetle names.

whose diet was $>50 \%$ sagebrush but lacked any cryptogams.

The remaining beetles are joined because cryptogams were a significant component of their diets. E. novoverrucula and Oxygonodera hispidula formed a subgroup whose diets consisted primarily of cryptogams and sagebrush. Stenomorpha puncticollis and Coniontis setosa formed another distinct subgroup characterized by a highly diverse diet with Jim Hill mustard a major component. The remaining beetles (Conisattus rectus, Eleodes hispilabris, E. granulata, P. densicollis, and E. nigrina) have a diverse diet with western tansymustard as a dominant component.

This study indicates that dietary distinctions are made by the tenebrioned beetles occupying our study sites. The underlying reasons for these distinctions are unknown but are probably related to temporal and spatial factors in addition to food preferences. Distributions of these beetles are related to soil texture, vegetation composition, and season (Sheldon \& Rogers 1984). Partitioning of food resources may be acting to refine further the niches of these beetles.

\section{Acknowledgment}

This paper is based on work supported by the Office of Health and Environmental Research under Department of Energy Contract DE-AC06-76RLO 1830. We thank Charles A. Triplehorn, Ohio State University, for the identification of beetles.

\section{References Cited}

Doyen, J. T. 1984. Systematics of Eusattus and Conisattus (Coleoptera: Tenebrionidae: Coniontini: Eusatti). Occasional Papers of the California Academy of Sciences 141.

Hansen, R. M. \& J. T. Flinders. 1969. Food habits of North American hares. Range Science Series No. 1, Colorado State University, Fort Collins.

Hartigan, J. A. 1975. Clustering algorithms. Wiley, New York.

Hinds, W. T. \& W. H. Rickard. 1973. Correlations between climatological fluctuations and a Philolithus densicollis (Horn) population (Coleoptera: Tenebrionidae). J. Anim. Ecol. 42: 341-351.

Hitchcock, C. L. \& A. Cronquist. 1973. Flora of the Pacific Northwest. University of Washington, Seattle.

Pianka, E. 1975. Niche relations of desert lizards, pp. 292-314. In M. L. Cody \& J. M. Diamond [eds.], Ecology and evolution of communities. Belknap, Cambridge, Mass.

Rickard, W. H. \& L. E. Haverfield. 1965. A pitfall trapping survey of darkling beetles in desert steppe vegetation. Ecology 46: 873-877.

Rogers, L. E. \& W. H. Rickard. 1975. A survey of darkling beetles in desert steppe vegetation after a decade. Ann. Entomol. Soc. Am. 68: 1069-1070.

Rogers, L. E. \& D. W. Uresk. 1974. Food plant selection by the migratory grasshopper (Melanoplus sanguinipes) within a cheatgrass community. Northwest Sci. 48: 230-234.

Sheldon, J. K. \& L. E. Rogers. 1984. Seasonal and habitat distribution of tenebrionid beetles in shrubsteppe communities of the Hanford Site in eastern Washington. Environ. Entomol. 13: 214-220.

Sparks, D. R. \& J. C. Malechek. 1968. Estimating 
percentage dry weight using a microscopic technique. J. Range Manage. 21: 264-265.

Steele, R. G. D. \& J. H. Torrie. 1969. Principles and procedures of statistics. McGraw-Hill, New York.

Stone, W. A., D. E. Jenne \& J. M. Thorp. 1972. Climatography of the Hanford area. BNWL-1065. Pacific Northwest Laboratories, Richland, Washington.
Wiens, J. A. \& J. T. Rotenberry. 1979. Diet niche relationships among North American grassland and shrub steppe birds. Oecologia 42: 253-292.

Received for publication 2 June 1986; accepted 18 March 1988. 